\title{
FATE AND PRODIGIES IN ROMAN RELIGION AND LITERATURE ${ }^{1}$
}

\author{
PETER KUHLMANN
}

Georg-August Universität Göttingen

\begin{abstract}
Resumen
La religión romana tradicional no conoce el concepto de un determinismo. La creencia en los prodigios y las prácticas de expiación no impiden la libertad de acción para los hombres. Sin embargo la filosofía estoica trata de armonizar la creencia en los signos divinos y las prácticas de expiación con el concepto de determinismo. Cicerón muestra la incompatibilidad del ritualismo romano con el determismo estoico. En los textos literarios como historiografía, biografía y epopeya los signos difieren de los prodigios de la religión tradicional y tienen funciones más bien narrativas, aunque presuponen una creencia general en este fenómeno. Como motivo literario el uso de prodigios perdura hasta la época cristiana, lo que muestra una gran continuidad cultural durante toda la historia romana.
\end{abstract}

Palabras clave: prodigio, expiación, signos, estoicismo, Cicerón, Livio, Seneca, Virgilio, Lucano, cristianismo.

\section{FATUM AND FATA}

The Latin term which corresponds to the English term of fate or Spanish destino respectively, is, in general, fatum. Whether this originally meant the same as (determined) "fate", is an entirely different question. The Latin word derives from fari "to say" and initially means "what has been said"2. In Latin epic poetry the expression is found several times in the plural fata deum "assertions of the gods" ${ }^{2}$, which may be founded on archaic ideas.

Fatum would not be conceived of in an abstract way, then, like in late stoicism, but as a particular declaration or will of the gods which, as such, affects people's lives. This is not to be understood as determinism - quite the contrary. The conception of a general predetermination of human actions or the course of history was foreign to traditional Roman religion. This, at any rate, can be inferred from the conjunction of

\footnotetext{
${ }^{1}$ Georg-August Universität Góttingen. Correo peter.kuhlmann@phil. uni-goettingen.de. Aceptado: 3101-2011.

${ }^{2}$ Walde and Hofmann, s.v. fatum.

${ }^{3}$ E.g. Verg. Aen. 2,54; 3,576; 6,376; Lucan. 1,599.
} 
Roman ritualism according to the principle of do-ut-des and the conception of prodigia and omina.

This paper illustrates the belief in prodigies in the context of Roman religion and subsequently the conception of signs and destiny in philosophy and literature.

\section{SIGNS AND PORTENTS IN ROMAN CULT}

\section{a) Prodigia}

According to traditional Roman conception the divine forces reveal their will through signs (Lat. signa). These divine signs as expressions of the will of the gods occurred in several ways: For one thing people could actively ask for the gods' approval of certain acts or undertakings through rituals; in Rome this was done by auspices or hepatoscopy ${ }^{4}$. But the gods could also send unrequested portents, or signa. Among those are the prodigies: They are signs of nature in the form of lightnings, earthquakes, apparitions of light or fire, eruptions, plagues of locusts, rain of stones or blood, sweating or bleeding statues of gods, but also monstrosities among humans and animals and more.

These prodigies (also called ostenta, portenta or miracula) are, because of their predominantly negative nature, indicative of a disturbance in the relation between gods and men, i.e. in the pax deorum ${ }^{5}$. Usually prodigies indicated a dissatisfaction of the gods and thus a threat to Roman political system and required an expiatio from the Roman authorities. ${ }^{6}$ By carrying out an expiation with the appropriate sacrifices the gods were reconciled and expected to warrant the salus rei publicae in return ${ }^{7}$. This reveals the rather public character of this sort of portents. They could be reported to the public authorities by private persons, in which case they had to be checked for validity by the senate and the consuls, priests (pontifices) could also be consulted.

Then the magistrates made a decision on the course of action and the possible execution of the necessary rituals of expiation, which could consist in offerings, collective prayers (supplicatio) or ritual cleansing (lustratio) of the city ${ }^{8}$. A forceful description of these rituals survives in the work of the Roman poet Lucan'.

From this system belief in a determined fate cannot yet be inferred: For one thing, prodigies are no real portents which signify a determined fate beforehand. And for another thing, men are in principle free in their actions, even though they might

\footnotetext{
${ }^{4}$ On this in general (Rosenberger 2007: 292-303).

${ }^{5}$ (Bloch, 1984: 79-86).

${ }^{6}$ Many examples of the rites in (Luterbacher, 1904: 33-43).

${ }^{7}$ On this contract-like relation between Roman state and the gods cf. (Scheid, 1997: 480-491); Rosenberger, 17-22.

${ }^{8}$ At length (MacBain, 1982); (Rosenberger 1997: 127-196).

${ }^{9}$ LUCAN. 1,584-615.
} 
incur the wrath of the gods afterwards. In the end men are also free to execute an expiation subsequent to prodigies or to refrain from doing so. They just have to accept the negative consequences which might result from that.

\section{b) Omina}

A second group of signs, by contrast, the omina, are indeed closer to being portents in the literal sense: For the most part, omens signify a near future and do not necessarily concern the public community, but individuals. They mainly occur in the form of seemingly casual utterances which signify a future event and thus often only reveal their sign character in hindsight. Names can be "ominous" too, i.e. involve a positive or negative omen. Hence omina are not connected with state cult. To cite a few examples: When the Roman senators considered abandoning the city and move to the neighbouring Veji after the destruction of Rome in 4 BC, they heard a soldier on watch say to his men: "Signifer, statue signum, hic optime manebimus." Having heard this, the senate conceived of the utterance as a good omen and as advice from the gods to stay in Rome. ${ }^{10}$ The Romans stayed in Rome and successfully built their vast empire after the Gaul catastrophe.

Many omina have survived in connexion with biographies of emperors, e.g. the naming of the new-born Nero ${ }^{11}$ : When Nero's mother asked her brother and thenemperor Caligula to give the little Nero a name, too, he jokingly called the baby with the name of his uncle Claudius, who was then considered a retarded simpleton, but later came to be emperor. The suggestion was not taken seriously, though, and was not put into action. But when Nero lost his father at the age of only three, he was adopted by Claudius and so actually received his name. This adoption, in turn, was the basis for Nero's later reign.

So omina really seem to indicate something like a predetermined fate; but apparently they are primarily a phenomenon of literary tradition since imperial times. In the case of Nero the omen conveys the impression that his negative character and his later reign were already predetermined by a divine will by the time of his birth.

\section{PRODIGIES IN PHILOSOPHICAL DISCOURSE}

\section{a) Signs and portents in the system of stoicism}

These questions touch on the relation between the will of the gods, human contribution and destiny in the framework of Roman religion. No later than by the $1^{\text {st }}$ century BC a long-lasting discussion about the relations between these factors and, thus, reflection on the nature and significance of divine signs had begun in Rome.

\footnotetext{
$\overline{{ }^{10} \text { VAL. MAX. 1,5. }}$

${ }^{11}$ Cf. SVEt. Ner. 6,2.
} 
Even in late antiquity pagan and Christian authors, still or again, exhibited a distinct interest in prodigies and omens. Scholarly and philosophical discussion about belief in prodigies and destiny was particularly promoted by the Stoics ${ }^{12}$, who have had many followers in Rome since late republican times and influenced the Christian authors of later times in many respects.

The Stoics tried to incorporate the concepts of prodigies and subsequent expiatory practice into their system of divine providence and to explain them rationally. According to the Stoics' conception, cosmos was pervaded by the divine spirit (Gr. logos, Lat. ratio). This divine logos or ratio governed all events in accordance with logical and rational principles. But because every event was causally predictable, this was already tantamount to a kind of determinism. Every event, however small, entails a series of additional events, which would be predictable for men, if they knew all natural processes. Thus the notion of luck has no place in life. Moreover the Stoics concluded that everything in cosmos was causally related in this way-cosmos is a self-contained system, in which everything is connected ("sympathetically") ${ }^{13}$. So it was believed that the correlation of portents and the corresponding historical events could be accounted for scientifically, too. Human misconduct could easily be somehow correlated with an earthquake or eruption which was perceived as a prodigy in this sympathetic conception of the world; omens worked because the future was predetermined in the Stoics' view.

Omens and Prodigies were incorporated into the Stoic doctrine of signs and were really considered signs for other processes, events or states of affairs in cosmos in the semiotic sense. Consequently many Stoics believed passionately in astrology, because an interrelatedness of human destiny and stellar constellations seemed scientifically explicable within the sympathetic world view. The Stoics also believed in a benevolent divine will which was in charge of the plan for the world and also fundamentally attentive to people (Gr. prónoia, Lat. providentia). The reason why the gods send humans signs in the form of omens and prodigies in the first place, lies in this providence: The humans were to receive warning advice from the gods to be able to arrange their lives accordingly.

From this the following logical problem arises: What sense can these divine signs have, if everything is predetermined anyway? Especially: What sense do public expiations and prayers to the gods have, if they cannot really have any effect on the will of the gods? For these rituals presuppose the possibility of human actions affecting the gods and their sentiments. The Stoics met these questions by developing a complex system to explain prodigies, the will of the gods and ritual acts: According to it all these elements are parts of the system of the Stoic fatum: Not only human misconduct and the subsequent prodigy are determined beforehand by this fatum, but so is the

\footnotetext{
${ }^{12}$ At length (Bobzien, 1998).

${ }^{13}$ Cf. Cic. diu. 2,124.
} 
requirement that an expiation has to be performed to restore order. Hence all religious rituals are necessary and, as it were, scientifically justifiable ${ }^{14}$.

\section{b) Cicero's Scepticism}

The disagreement provoked by this model for explaining the world is hardly surprising. One faction of platonism needs to be mentioned in the present context: scepticism, of which Cicero was the most prominent follower in Rome ${ }^{15}$. The sceptics raised doubts about any seemingly certain knowledge and consequently abstained from a definite judgement about the existence of gods. Cicero, who was himself in charge of the interpretation of signs in his sacerdotal capacity as an augur, composed his dialogue de divinatione shortly before his death. In its first volume he makes his brother Quintus expound the Stoic account of the aforementioned problems and replies in the second volume as the dialogue partner from a sceptical point of view ${ }^{16}$.

He criticizes, for instance, the unproven assumption of divine care: Even if the gods exist, they by no means need be attentive and care for humans through prodigies. And prodigies and omens are not considered signs of care at all: For what is the use to men, if they know of their ill fortune which they cannot change beforehand? It is much more humane, then, to leave them in the dark as long as possible ${ }^{17}$. Either you cannot call it a thoughtful "warning" or there is no fatum: For if you - having been warned by signs - can avoid your misfortune, the fatum is vain or the prodigy/omen is not a sign of the inevitable fatum $^{18}$.

Cicero seems also to recognize correctly that the Stoics misconstrue the Roman understanding of rituals with its distribution of the roles of men and gods: Roman ritualism presupposes the very possibility of free choice on the part of men and gods alike: Men are not at all forced to perform the expiations. Nor are they really constrained in their actions by the gods: After the expiatory ritual one has full opportunity to make his decisions again. Hence it becomes clear that the traditional Roman concept of the will of the gods cannot be identified with the Stoic fatum.

For the central aspects of human life the entire practice of divination is utterly unimportant anyway, according to Cicero ${ }^{19}$. Nobody in Rome - so he contends - would base his conduct in ethical matters - e.g. his behaviour towards relatives or friends - on prodigies or auspices. In choosing the best form of government these religious forms do not play a role, either; when looking for the best constitution, you do not ask a priest or an augur but an expert in politics. Thereby Cicero draws a clear distinction

\footnotetext{
${ }^{14}$ Cf. SEN. nat. quaest. 2,34ff.

${ }^{15}$ Another critic of prodigies and the concerning rituals is the Epicurean poet Lukretius $\left(1^{\text {st }}\right.$ century BC), who explains the alleged "portents" in a purely scientific way (LVCR. 5,1161-1240).

${ }^{16}$ On this in general (Kuhlmann 2008: 178-182).

${ }^{17}$ Cf. Cic. diu. 2,21-22.

${ }^{18}$ Cf. CIC. diu. 2,20.

${ }^{19}$ Cf. Cic. diu. 2,9-11.
} 
between philosophy and religion, insofar as it relates to the actual cult and the relation to the gods. Quite sagaciously he asks for a logically coherent definition of prodigies, omens and divine signs in general. He sees a lack of semantic connexion between sign and the thing denoted, i.e. he stresses the ambiguity of the alleged signs ${ }^{20}$.

In Rome, for example, a lightning was considered a good sign if it struck from the left, in Greece, in contrast, if it struck from the right ${ }^{21}$. This also shows the need for expert knowledge in ascertaining divine knowledge. In this context Cicero asks ironically, why gods are unable to disclose their will directly and unambiguously to the humans and why they are dependent on these often useless means. He rightly remarks that the assessment of prodigies is ultimately arbitrary and rests on human interpretation, that indeed the very sign character of natural phenomena as supposed prodigies itself rests on human construction ${ }^{22}$.

Finally it is interesting that the augur Cicero himself points out in his dialogue about soothsaying, how many divine signs there were during the turmoil of the civil wars, which, for the most part, did not at all mean what the priests had ascribed to them. The losers of the civil wars were promised victories and the winners were advised against important ventures and battles by the priests ${ }^{23}$. Hardly anything came true.

\section{PRODIGIES AND OMENS AS A LITERARY PHENOMENON}

Perhaps the many false predictions and sacerdotal mistakes of the civil wars led to a crisis of confidence in the reliability of prodigies of the $1^{\text {st }}$ Century BC. In any case Cicero does not seem to be the only one who did not trust the divine signs anymore ${ }^{24}$. Also striking is the absence of prodigies in the historiography of that time, although their mentioning used to be an integral part of the genre: Sallust, for example, takes virtually no notice of them. Caesar does not mention a single prodigy in his historical works. The only refuge for these signs is epic poetry. Cicero, for instance, did make use of this motif both in his epic about Marius and in his autopanegyric epic poem de consulatu suo, in which he gloryfies his own consulship over the course of three volumes. His brother Quintus points to that, too, in Cicero's work about soothsaying and cites the passages verbatim ${ }^{25}$ : Cicero described the occurrence of comets, lunar eclipses, pillars of fire in the sky and lightning prodigies which were supposed to have

\footnotetext{
${ }^{20}$ Cf. CIC. diu. $2,15-20 ; 2,62 \mathrm{f}$.

${ }^{21}$ Cf. Cic diu. 2,82; see also (Wülker, 1903: 9f.).

${ }^{22}$ Cf. Cic diu. 2,66f.

${ }^{23}$ Cf. Cic diu. $2,53$.

${ }^{24}$ At length on the different theories about the alleged decline of prodigy rituals in recent scholarship (Rosenberger, 1997: 197-240).
}

${ }^{25}$ Cf. Cic diu. 1,17; 106. 
hinted at the Catilinian Conspiracy ${ }^{26}$. Yet these are merely literary topics that cannot be considered historical truths ${ }^{27}$.

In subsequent times prodigies do not play a noteworthy role in Rome's public life at first: Augustus interestingly abstains from collecting and interpreting prodigies, although otherwise he was an eager restorer of ancient Roman faith ${ }^{28}$. In his writings the Augustan historian Livy explicitly bemoans the neglect of prodigies in his time ${ }^{29}$. As a compensation he mentions all the more prodigies and omens which accompanied Rome's history in his historical work - especially for the early days. The question whether Livy himself really believed in the existence and significance of these signs, is not easy to resolve, though. He writes: "I am not unaware that the heedlessness underlying the widespread modern refusal to believe that gods issue portents also causes prodigies no longer to be announced in public or included in the historical record. Nevertheless, as I write about bygone affairs, my mind in some way takes on an antique cast... ${ }^{3 \prime \prime}$

From this it could almost be concluded that the presentation of the prodigies was more intended to serve the antiquarian atmosphere of historiography ${ }^{31}$.

In the literary tradition of the time "prodigies" or signs play an important role: For Rome's early days Livy relates several rather unique portents, which cannot be classified in the system of Roman cult tradition. One example is the fiery corona around the young Servius Tullius's head that presages his future reign ${ }^{32}$.

Another example of purely literary prodigies are the ones in Virgil's Aeneid: They often tend to resemble Greek ideas and considerably follow Homer in their types $^{33}$. Contrary to Roman custom they can both bode well and ill. Very famous is the following prodigy in Vergil ${ }^{34}$ : Aeneas finds a white sow at divine behest, by which the gods signify to him the right place for founding his first city in Italy. By virtue of its type alone this sign does not fit into the system of Roman prodigies, because the functionalization of a white sow as a divine sign is singular in Roman tradition. Real Roman prodigies can always be classified with the aforementioned, numerically limited categories (e.g. lightnigs, monstrosities, etc.) $)^{35}$.

\footnotetext{
${ }^{26}$ Cf. CIC diu. 1,17.

${ }^{27}$ Cf. CIC diu. 2,54.

${ }^{28}$ Cf. (Bloch, 1984: 147f.).

${ }^{29}$ Cf. Liv. 43,13,1.

${ }^{30}$ Liv. 43,13,1. Translation by J. D. Chaplin.

${ }^{31}$ On similar tendencies of elaboration in Virgil's depiction of prodigies cf. (Grassmann-Fischer, 1966).

${ }^{32}$ Cf. LIV. 1,39.

${ }^{33}$ At length (Grassmann-Fischer, 1966).

${ }^{34}$ Cf. Verg. Aen. 8,81-83.

${ }^{35}$ Similarly the well-known bread prodigy VERG. Aen. 3,245-257.
} 
This shows how un-Roman the Aeneid really is, especially in a religiouscultish respect: Not only clashes the plot's stoicism-influenced determinism with the understanding of freedom of human actions towards the gods as outlined above; the divine signs of the Aeneid have nothing to do with Roman cult practice. This also stands out, because Cicero in his epic de consulatu suo as well as even Lucan use quite Roman prodigies; needless to say, however, that they also have a literary function insofar as they are purposefully used in outstanding passages to signal a peripeteia in the plot.

Another example are the signs - comparable to Livy - which indicate the splendor of a future ruler or hero, like the flames at the young Ascanius's head ${ }^{36}$, which refer back to the burning city of Troy as well as to his future reign. The flame prodigy of Lavinia $^{37}$ in book 7 is to be interpreted in a similar way ${ }^{38}$. The flames indicate both the wars and Aeneas's reign by Lavinia's side, which Virgil's narrator explicitly hints at.

In contrast to Roman state cult these signs tend to be favourable like, e.g., the well-known table prodigy of the Aeneid ${ }^{39}$, that denotes the arrival of the Aeneads in their new and ultimately predestined home. Thus these literary signs are - unlike usually done in modern scholarship - to be seperated strictly from the prodigies of the cult and are distinguished by the following features: They are usually favourable, they are embellished very individually, they indicate the predetermination of the fatum through their symbolic character and, of course, they do not require expiatory rites.

Prodigies and omens play a prominent role in the beginning of the $2^{\text {nd }}$ century AD in the writings of the author and imperial scribe Suetonius. This biographer mentions all important prodigies and omens from the emperor's life in a seperate category at the end of the biography. Many of these signs are presented as facts and their facticity is not qualified by remarks like "it is recorded that". As of now prodigies are now becoming an invariable topos in all of Graeco-Roman biography and historiography ${ }^{40}$.

Particularly illuminating are the Christian writers like St Augustine and his student and contemporary, the historian Orosius ${ }^{41}$ : They by no means deny the existence and supernatural provenance of signs. Orosius, for instance, mentions for Rome's republican days prodigies like fiery apparitions in the sky, bread which bled when broken, rain of stones, flames blazing into the sky from cracks in the earth and more $^{42}$. The Christian explanation for the facticity of such miraculous signs is twofold: Like most ancient Christian writers Augustine holds on to the existence of pagan gods. But he disparages them as demons, who are indeed capable of performing miracles

\footnotetext{
${ }^{36}$ Cf. Verg. Aen. 2,680-686.

${ }^{37}$ In general on this funtion of prodigies in Roman narrative literature (Feeney, 2007: 136-140).

${ }^{38}$ Cf. Verg. Aen. 7,71-80.

${ }^{39}$ Cf. Verg. Aen. 7,107-134.

${ }^{40}$ On this Kuhlmann (2002: 45f).

${ }^{41}$ At length (Martínez Cavero, 1997).

${ }^{42}$ Cf. Oros. 5,18.
} 
to deceive men's senses ${ }^{43}$. Orosius on the other hand sees the prodigies, the number of which increased in the $1^{\text {st }}$ century BC, as a sign of the decay of Roman society, that occurred during the civil wars ${ }^{44}$. So on Christian side a firm belief in the existence and significance of prodigies - even retrospectively in pagan times - apparently has to be reckoned with.

\section{CONCLUSION}

This paper has shown that, originally, there was certainly no conception of fate in the sense of a total determinism. Especially the belief in prodigies and the practice of expiation in the framework of state cult display to the contrary a great freedom of human action within the do-ut-des principle. Nonetheless, attemps to harmonise signs, expiatory rituals and determinism were made in the Stoic discourse. Yet these models misconstrue the fundamental concepts of Roman religion and interpret the relation between gods, men and destiny in a different way than is inherent in Roman religion: I.e. the Stoics are anything but "typically Roman" in this respect.

Furthermore a sharp distinction between the real prodigies of Roman cultreligion and the individually embellished signs in certain literary genres like epic poetry and historiography appears to be necessary: Here, too, becomes apparent: At least the notion of destiny of the Aeneid, which manifests in the signs, is far from being "typically Roman". In the literature of the high empire literary and fictional mechanisms are in operation which prevent the forming of an entirely clear picture: On the one hand the prodigies are literarily elaborated, on the other hand they presuppose a fundamental belief in divine signs on the reader's part.

Here again the continuity in the works of some historians is striking: The catalogue of prodigies, for example, of historians of imperial times includes the same prodigy-types as passed down from republican times. In the simultaneously emerging Christian faith belief in prodigies and miracles has been a constant feature from the very beginning and exhibits conspicuous structural analogies to the pagan-Roman model. This once more shows a strong cultural continuity from early imperial times through late antiquity.

\section{REFERENCES}

Beard, M. y North, J. (ed.) (1990): Pagan Priests. Religion and Power in the Ancient World, London.

Bloch, R. (1984): La divination dans l'antiquité, Paris.

Bobzien, S. (1998): Determinism and Freedom in Stoic Philosophy, Oxford.

Céard, J. (1977): La nature et les prodiges, Geneva.

\footnotetext{
${ }^{43}$ Cf. Avg. ciu. 2,24f.; 3,7.

${ }^{44}$ Oros. 4,13,12. On these aspects cf. Schmidt, 231f.
} 
Feeney, D. (2007): “The History of Roman Religion in Roman Historiography and Epic", in Rüpke, J. (ed.) A Companion to Roman Religion, Oxford, 129-141.

Grassmann-Fischer, B. (1966): Die Prodigien in Vergils Aeneis, Munich.

Kuhlmann, P. (2002): Religion und Erinnerung, Göttingen.

Kuhlmann, P. (2008): “Die Macht des Numinosen. Prodigien und Götterwille in Rom”, in Kratz, R. G. and Spieckermann, H. (eds.), Vorsehung, Schicksal und göttliche Macht, Tübingen, 171-192.

Luterbacher, F. (1904): Der Prodigienglaube und Prodigienstil der Römer, Burgdorf.

MacBain, B. (1982): Prodigy and Expiation, Brussels.

Martínez Cavero, P. (1997): “Signos y prodigios. Continuidad e inflexión en el pensamiento de Orosio", in Antigüedad cristiana 14, 83-95.

Rosenberger, V. (1997): Gezähmte Götter. Das Prodigienwesen der römischen Republik, Stuttgart.

Rosenberger, V. (2007): "Republican Nobiles: Controlling the Res Publica”, in Rüpke, J. (ed.) A Companion to Roman Religion, Oxford, 292-303.

Scheid, J. (1997): “Römische Religion”, in Graf, F. (ed.), Einleitung in die lateinische Philologie, Stuttgart.

Schmidt, P. L. (1968): Iulius Obsequens und das Problem der Livius-Epitome, Wiesbaden, 469-491.

Walde, A. y Pokorny, J. (19654): Lateinisches etymologisches Wörterbuch, Bd. I, Heidelberg $1965^{4}$.

Wülker, L. (1903): Die geschichtliche Entwicklung des Prodigienwesens bei den Römern, Leipzig. 